\title{
Јелка Ређеп
}

\section{САВИНСКИ РУКОПИС „ЖИТИЈА КНЕЗА ЛАЗАРА”}

Међу рукописима манастира Савине, у 3борнику апокрифа из друге четвртине 18. века, налази се и једна, досада непозната, варијанта Жиmија кнеза Лазара: „ПОВЕСТ ЖИТИЯ КНЕЗА ЛАЗАРА И ВОИВОДЕ МИЛОША И ЮСТАЛЕ ГОСПОДЕ СРБСКЕ ИЖЕ БИСТ НА ПОЛУ КОСОВ8". Овај текст представља 36. варијанту Житија, познатог у науци као Прича о боју косовском. По времену настанка, спада међу најстарије рукописе, настале на југу, у Боки Которској или Црној Гори. Ако се има на уму духовна клима у манастиру, и то поготово у 18. веку, онда постојање рукописне Приче и у Збирци старих савинских рукописа, не изненађује. Тек у 18. веку манастир Савина је од мало познате монашке заједнице прерастао у знаменито духовно средиште Срба у Боки. Његова континуирана историја почиње после 1693. године, када су избегли монаси из порушеног манастира Тврдоша дошли у Савину у збег, те су се тако спојила два братства из два манастира, Тврдоша и Савине. Од тог времена, „манастир Савина био (је) испуњен старинама од велике вредности које су некада припадале манастиру Милешеви, а касније Тврдошу". Тада наступа период богаћења и процвата. Како су из манастира Тврдоша пренете честице моштију св. Ђорђа, које је традиција везивала за св. Саву, обновљен манастир Савина је легитимно продужавао и светосавску традицију, те се убрзо претворио у велико и опште светилиште.

У својој монографији о манастиру Савини르, Дејан Медаковић је показао колико је манастирска збирка јединствено сведочанство и доказ интензивних укрштања разних култура. „Ови троструки изукрштани културни утицаји, домаћи, левантински и руски, посведочени су у манастиру Савини не само у делима која припадају црквеном сликарству"з,

1 Дејан Медаковић, Манастир Савина, Београд, 1978, 67.

2 Дејан Медаковић, Манастир Савина, Велика ирква, Ризнии, Рукописи, Београд, 1978.

3 Нав. дело, 64. 
већ су присутни и на многим предметима примењене уметности, на сасудама, на текстилу. Но манастир Савину Медаковић не посматра само као изузетан споменик, већ, пре свега, и као важно духовно средиште Срба у Боки Которској. „По нашем мишљењу овакав значај је постигнут највише зато јер је манастир Савина сачувао своју трајну повезаност са бунтовним херцеговачким залеђем, одакле су црпени и сви битни подстицаји за ону мисију која је постепено сазревала међу савинским калуђерима"4.

После одлуке млетачке владе од 12. маја 1718. - којом је признала црногорском митрополиту Данилу јурисдикцију над целом Боком Которском - омогућено је не само повезивање Савине са залеђем, већ и отварање према утицајима са разних страна, те је тако Савина претворена у јединствено средиште православне цивилизације. У Савини се „родио и дух изузетног историзма који је посведочен не само уметничким делима са стране, већ и онима која су настала у манастиру"5.

Историјат манастира Савине показује да ни у 18. веку „манастир није постао средиште неког уметничког или књижевног стварања". Књиге, као и многи други дарови, стизали су у Савину са различитих страна. Нажалост, немамо сазнања да ли је 3борник апокрифа, у коме се налази и рукиописна Прича, донет или је преписиван у манастиру.

Опис 3борника апокрифа дао је Димитрије Богдановић у Инвентару рукописа манастира Савине под бр. 30. Богдановић је сачинио сажети Инвентар, уз стару дао је и нову сигнатуру, рукописе је средио по врсти односно садржини а у обради рукописа презентирао је најнеопходније елементе 7 . Датирање рукописа манастира Савине Богдановић заснива на „филигранолошкој анализи, мада су узети у обзир и други, палеографско - кодиколошки и историјски моменти". Тако за Зборник апокрифа сматра да је настао у другој четвртини 18. века. Писан је на хартији, има 127 листова, формата 140x100 мм. Веома је оштећен. Кожни повез. Српска редакција, посрбљени правопис; примитивни брзопис. Зборник је писало више руку. Нема орнаментике.

4 Нав. дело, 66-67.

5 Нав. дело, 67.

6 Нав. дело, 26.

7 Димитрије Богдановић, Инвентар рукописа манастира Савине, Дејан Медаковић, нав. дело, 89-96.

${ }^{8}$ Нав. дело, 90. 
Садржину 3борника чине:

Апокрифни текстови (Трепетник, Гатарник, Громовник, Лекаруша, Виђење свете литургије итд.)

„Повест житија кнеза Лазара и војводе Милоша и остале господе српске иже бист на пољу Косову”.

Разне белешке9.

Повест житија кнеза Лазара... налази се у 3борнику од 90-121. листа. Текст су писале две руке. У првом рукопису има српскословенских речи, док их у другом нема и језик је више народни.

Савински рукопис Житија односно рукописне Приче о боју косовском пореклом је са југа, баш као и најстарије варијанте, Рукопис Михаила Милорадовића (ММ) из 1714-1715, Рукопис Универзитетске библиотеке (УБ) настао између 1715-1725. и Грујићев рукопис (Г) из 1727, те је занимљив однос Савинског рукописа $(\mathrm{CA})^{10}$ према овим, али и према свим осталим варијантама. Упоређујући 25 варијаната рукописне Приче ${ }^{11}$, а потом и Рукопис Максима Гавриловића (1721), $М \Gamma^{12}$, и Рукопис Николе Лазаревића (НЛ $)^{13}$ из 1735. са овима, дошли смо до уверења да постоје разлике у детаљима, али нису суштинске и не односе се на другачији ток приче. Видљива је испреплетаност варијаната, постоје разлике у комбинацијама и варирања код појединих рукописа, но не би се могло говорити о две, потпуно различите групе рукописа. Пре се могу уочити два тока, која су се рано почела одвајати од протографа, те су временом млађи и каснији преписи следили те токове, а то су два међу најстаријима, рукописи УБ и $\Gamma^{14}$.

Наслов Савинског рукописа (СА), и поред сличности са већином варијаната, најближи је наслову рукописа ИЈ и ЛВ.

9 Опис Зборника апокрифа дали смо на основу описа Димитрија Богдановића, нав. дело, 95.

${ }^{10}$ Надаље шифра за Савински рукопис СА.

${ }_{11}$ Јелка Ређеп, Прича о боју косовском, Зрењанин, 1976, 31-159.

12 Јелка Ређеп, Зборник Максима Гавриловића, Зборник МС за славистику, Нови Сад, бр. 25/1983, 77-89.

13 Једно непознато „Житије кнеза Лазара”, Свети кнез Лазар, Споменица о шестотој годишњици Косовског броја 1389-1989, у Београду, 1989, 303-310.

14 У раду ћемо користити шифре рукописа установљене у књизи J. Ређеп, Прича о боју косовском, 31-34. 
Самодржаць

кнез Лазарь

отачаства

рода

и племена нарочита

благородни

родителъ

да служитъ

по заповеди

самодржца

цара Стефана

(н)a

то

време

на

царство

юрошево

и

вбише

цара

малога

на

Марици
ММ МГ Г НЛ В МЈ ИЈ К НБ 433 АМ СУД ПН С ГК ДК СГ Б ТН ПМ

ММ МГ Г НЛ В МЈ ИЈ К НБ 433 АМ СУД ПН ЛВ С ГК ДК СГ Б ТН ПМ

ММ Г ЛВ ИЈ НБ 433 АМ ПН СБ МС

ММ МГ Г НЛ МЈ ЛВ ИЈ К АМ СУД ГК Б ДК МС

ММ МГ Г НЛ МЈ ЛВ ИЈ НБ 433 К АМ СУД ПН С ГК ДК СГ Б ТН

ММ МГ НЛ ЛВ ИЈ НБ 433 АМ ПН СУД ГК

С ДК МС ПМ

ММ Г В МЈ ЛВ ИЈ К НБ 433 АМ СУД ПН С

ГК ДК СГ Б ТН ПМ

ММ МГ МЈ ЛВ

ММ УБ МГ НЛ В МЈ ЛВ ИЈ ПН ГК С ДК

ММ УБ МГ НЛ В МЈ ИЈ ПН

ММ УБ МГ НЛ В МЈ ЛВ ИЈ ПН ГК С ДК MC TH

УБ МГ НЛ ИЈ ПН ГК С ДК СГ

ММ УБ МГ НЛ МЈ ИЈ ПН ГК ЛВ С ДК МС TH CГ

ММ УБ МГ НЛ МЈ ИЈ ЛВ ПН ГК С ДК МС ТН СГ

ММ УБ МГ НЛ В МЈ ИЈ ЛВ СУД ПН ГК ДК СГ МС ТН ПМ

ММ УБ МГ Г НЛ В МЈ ИЈ К НБ 433 АМ

СУД ПН ГК ЛВ С СГ ДК ТН ПМ

МЈ ИЈ ЛВ

ММ УБ МГ НЛ В МЈ ИЈ НБ 433 СУД ПН С

ГК ЛВ Б МС ТН ПМ

ММ УБ МГ Г НЛ В МЈ ИЈ К ПБ 433 АМ

СУД ПН С ГК ДК Б СГ МС

СГ

уБ НЛ МJ

ММ УБ МГ Г НЛ МЈ ИЈ К ПН С ГК ЛВ СГ ДК МС ТН ПМ НБ 433 АМ СУД Б

ММ УБ МГ Г НЛ ИЈ МЈ К ПН ГК ЛВ СГ ДК

МС ТН ПМ НБ 433 АМ СУД Б 


\begin{tabular}{|c|c|}
\hline погвблено бистъ & УБ МГ Г К СУД ГК МС ПМ \\
\hline.$\check{0 .}$ & уБ ПН С ДК СГ \\
\hline хилада & ММ УБ МГ НЛ С СГ ДК МС \\
\hline свдъ & $\begin{array}{l}\text { ММ УБ МГ НЛ МЈ ЛВ ИЈ К НБ } 433 \text { АМ ПН } \\
\text { ГК ДК Б СГ МС }\end{array}$ \\
\hline божи & $\begin{array}{l}\text { ММ УБ МГ НЛ МЈ ЛВ ИЈ К НБ } 433 \text { АМ ПН } \\
\text { ГК ДК Б СГ МС }\end{array}$ \\
\hline приеше & ММ УБ МГ МЈ ЛВ К \\
\hline за & $\begin{array}{l}\text { ММ УБ МГ НЛ В К НБ } 433 \text { АМ ПН С ГК } \\
\text { ДК Б МС }\end{array}$ \\
\hline ни & ММ УБ МГ Г НЛ В ПН ГК \\
\hline лұкавство & УБ МЈ ИЈ ЛВ \\
\hline господа и брача & ИЈ \\
\hline Мрнавчича & ММ УБ Г В МЈ ЛВ ИЈ К \\
\hline на & Мм УБ НЛ В МЈ ЛВ ИЈ ПН ДК МС \\
\hline TOM8 & ММ МЈ ЛВ ИЈ \\
\hline бою & ММ УБ МГ НЛ В МЈ ЛВ ИЈ ПН ДК МС \\
\hline Вука и Костадина & ЛВ (Константина) \\
\hline Паязиту & ММ МГ Г ИЈ НБ 433 ПН С ГК ТН СГ \\
\hline промисломъ & ММ МГ г НЛ В МЈ ИЈ ПН С ГК СГ ДК \\
\hline божиемъ & ММ МГ Г В МЈ ИЈ ПН СГ \\
\hline ставише & ММ НЛ ПН СГ ТН \\
\hline васего & $\begin{array}{l}\text { ММ МГ В МЈ ИЈ К НБ } 433 \text { АМ СУД ПН ГК } \\
\text { ДК Б СГ МС }\end{array}$ \\
\hline сабора & $\begin{array}{l}\text { ММ МГ Г НЛ МЈ ИЈ К НБ } 433 \text { АМ СУД ПН } \\
\text { ГК ДК СГ МС }\end{array}$ \\
\hline свакому & ММ ПН СГ \\
\hline добря & НЛ МЈ ПМ \\
\hline правом & ИЈ \\
\hline свд૪ & ММ МГ НЛ В МЈ ЛВ ИЈ ПН С \\
\hline податливе & $\begin{array}{l}\text { ММ МГ Г НЛ МЈ ЛВ ИЈ НБ } 433 \text { К АМ СУД } \\
\text { ПН С ГК СГ МС }\end{array}$ \\
\hline двие & Г В МЈ ЛВ НБ 433 ПН ДК ПМ \\
\hline дащери & В МЈ ЛВ НБ 433 АМ ПН С ДК Б СГ \\
\hline дата & МЈ ЛВ ИЈ \\
\hline Вук8 & Г К НБ 433 СУД С \\
\hline за & $\begin{array}{l}\text { ММ МГ НЛ В МЈ ЛВ ИЈ ПН С ГК ДК СГ } \\
\text { МС ТН }\end{array}$ \\
\hline
\end{tabular}




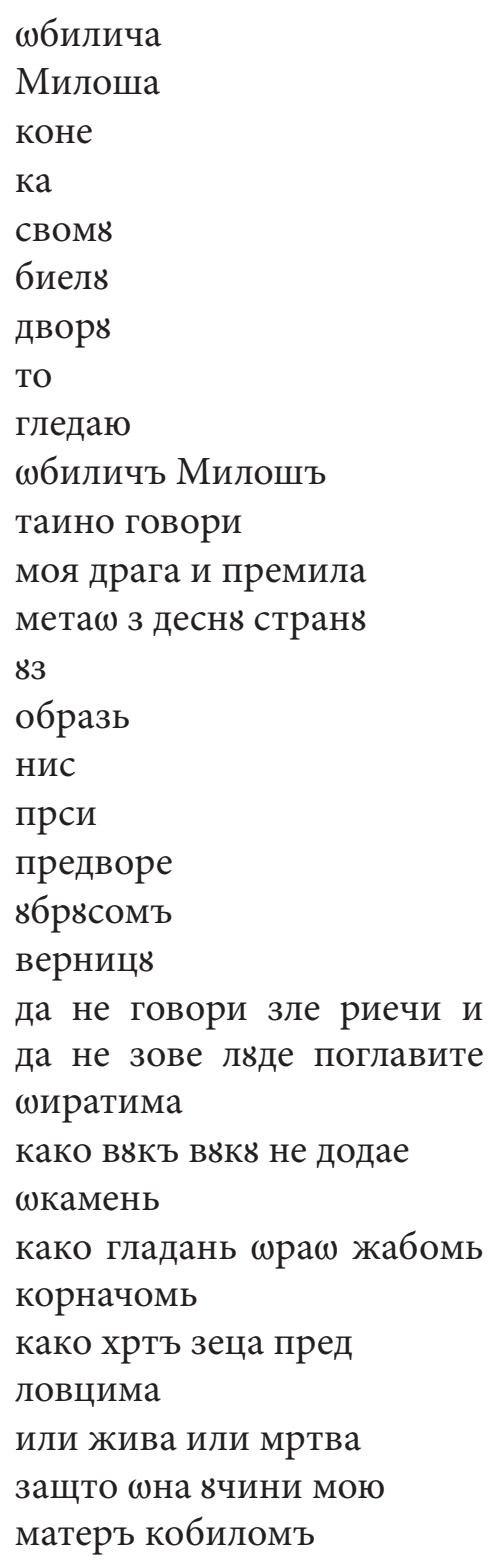

НЛ

НЛ

В С МЈ ЛВ ИЈ

УБ МГ Г НЛ В МЈ ЛВ К СГ

НЛ ИЈ СГ

ЛВ СГ (биелому)

УБ МГ Г НЛ В ИЈ МЈ К ПН ГК ДК СГ ТН

УБ МЈ ЛВ ИЈ СГ

УБ МГ НЛ В ГК СГ МС ТН

МЈ ЛВ

В ЛВ

МЈ ИЈ ЛВ СГ

ЛВ ИЈ СГ

УБ Г НЛ В МЈ ЛВ ИЈ К СГ ТН ПМ

УБ НЛ В МЈ ИЈ ЛВ ГК СГ ТН ПМ

УБ НЛ В МЈ АМ СУД ПН С ГК Б СГ МС ТН

МГ Г НЛ В МЈ ЛВ ИЈ К АМ С Б СГ

Г НЛ К ИЈ С СГ ПН

МГ Г НЛ К ИЈ Б МС В СГ МЈ С

НЛ ИЈ СГ

НЛ СУД ИЈ ГК

УБ ИЈ ЛВ

МГ ИЈ СГ ЛВ

Мј НЛ СГ УБ В ИЈ Пн Мј Лв

МГ НЛ МЈ ИЈ СГ ПН ЛВ

ИЈ СГ МЈ ЛВ

МГ г УБ В Нл МЈ ИЈ ЛВ СГ

И док се у рукописима, УБ МГ НЛ МЈ САН 134 ИЈ СГ ПН МС АМ Б ТН и СА каже нека сваки зна шта учини (Милош) Обилић, то не налазимо у рукописима Г К СУД ДК Р ЛВ ПМ. 


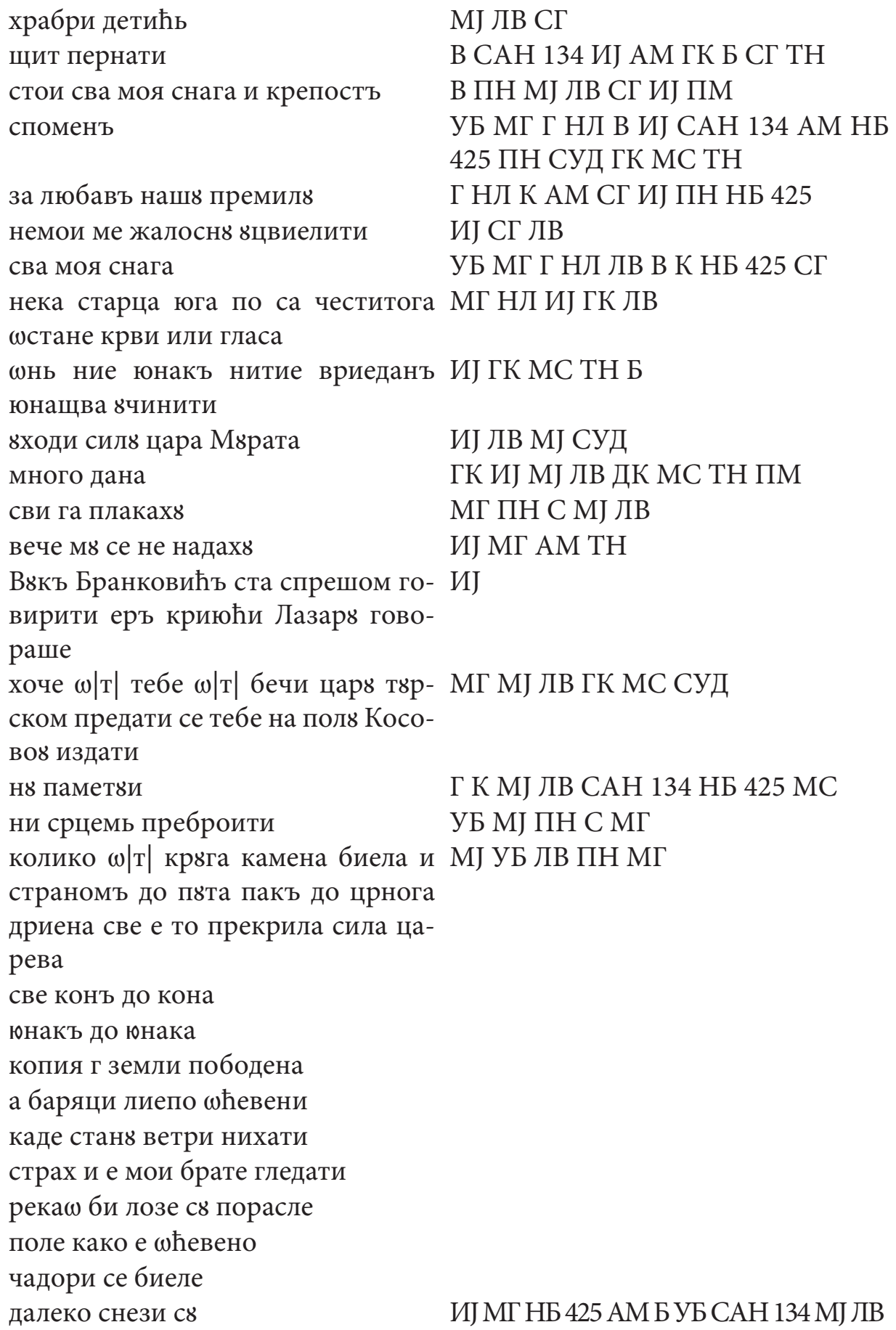


сви мв ради бише како летв по злои ИЈ АМ МJ САН 134 п зими

ивниа Дї данъ 14. јуно помињу ру- УБ Г НБ 425 ПН СУД кописи

бвди веранъ и вино попи и на даръ УБ МГ ПН МЈ ЛВ САН 134

ти златанъ пехаръ и не бвди неве-

ранъ него прими све 8 даръ

Крушевац ми стари беше даровати МЈ ЛВ П УБ МГ Б

тко е вера тко ли е невера

Г ГК СУД МЈ ЛВ П

како вихаръ ветаръ

УБ С П МГ САН $134 \mathrm{MJ}$

кад се сакриваю ноћни мраци и МГ МЈ ЛВ САН 134 ПН С ГК МС даница са звездами и када санце ДК ТН П ПМ

пвсти тракове и св8 свою светло-

стъ по земли

ние 8 законв царевв да паше ристя- МЈ ЛВ П

номъ коне примаю

него хочв твои животъ примити СМ ЛВ САН 134 ГК МС ДК ТН Р на даръ

тенефе

кличе како женски глас

Милоша жива твога крвника

УБ ПН

сваки господинъ свою самртъ ляби УБ САН 134 ГК МС ТН

шставите га садъ жива

бвбни вдарише и Лазареве борие

седам илада до(брие) юнака

УБ ПН ГК МС ЛВ СМ

прими га без мита на даръ

ЛВ СМ Г УБ ГК

брзо три стиене начините $\omega \mid$ т| би- ЛВ СМ ПН

ела мрамора

Милошь цара швди вби а сам себе П ЛВ

їзгвби

гробь $\omega \mid$ т $\mid$ мрамора са златом

УБ

Завршетак рукописа СА одговара рукописима, ЛВ и СМ, каже се да иза кнеза Лазара остаје госпођа Милица са синовима, па се ређају синови, кћери и зетови Лазареви ${ }^{15}$.

Упоређујући СА рукопис са осталима, може се запазити да је он најближи рукописима ИЈ ЛВ МЈ ММ УБ НЛ СГ В, па тек онда Г. Поједи-

15 У раду нисмо навели све примере које смо поредили већ само известан број, како би се стекао утисак о сродности СА рукописа са другим варијантама. 
ни текстови нису сачувани у целини (пр. ММ, СГ) или им недостаје по која страница (пр. УБ), те ни добијене бројне вредности не могу бити прецизне ${ }^{16}$. Нема сумње, међутим, да је СА рукопис ближи рукописима међу којима су најстарији рукописи УБ и ММ, но варијантама које показују веће сродности са Г рукописом. Рукописе МЈ и ЛВ, веома блиске СА, користио је Стојан Новаковић за свој свод ${ }^{17}$, али је СА старији од поменутих (МЈ - 1745, ЛВ - 1788). СА је старији и од рукописа ИЈ (1750), са којим такође има много сличности. То указује на могућност да су сви ови рукописи могли бити преписивани са истог предлошка.

Занимљива је чињеница да је СА рукопис врло сличан најстаријим варијантама Приче са југа, рукописима ММ и УБ. Рукопис ММ се налази у Рукописном зборнику Михаила Милорадовића (422 л.), који је нађен у манастиру св. Луке у Жупи никшићкој а састављен и преписан у Москви 1714-1715. године, а у одломцима га је објавио Павле Ровински ${ }^{18}$. Драгоцене су белешке у Зборнику, јер из њих сазнајемо да је Никола Лекович 1735. донео 3борник из Москве у Никшић ${ }^{19}$, па је он касније припадао унуку Симеона Лаиновича, Димитрију Попову ${ }^{20}$, но свакако је најинтересантнија она у којој се говори о настанку књиге (л.419):

„Си летопись у господина архимандрита Аничи требинскога, брата владике Петрони словинскога, и речени владика Петроние исписао га из летописа требиньскога. - А преписа га Никола властелиновичь ва царствующим градь Москве у двору Ивана Свирчькова на Покровки; а то на квартиру господина полковника и кавалиера Михаила Милорадовича. А преписа га с великиемь трудомь и подвигомь; просимь и молимь читущта погрешно благословите, а не клните. Се же бисть при диржаве благочастиваго цара и великаго кнеза Петра Алексиевича самодржца, и при благородномь Алексиемь Петровичемь ва царствующтемь граде Москве ва лето от рождества Христова 1715. год. месеца геньвара 14 - Савирьшисе дань, и му га потписа за вечу веру своею рукою, будучи цароставникь неговь и негова трудаа и подвигь бивши заедно на квартиру”. Своје-

${ }^{16}$ С обзиром да смо у раду навели мањи број примера, нисмо унели добијене бројне вредности.

17 Стојан Новаковић, Народна предана о боју косовском, побележена прве поле 18. вијека, Старине ЈАЗУ, Х, 176-200.

18 Павле Ровински, Рукописни Зборник Михаила Милорадовића, ЛМС, 1895, књ. 181, св. прва, 40-67; књ. 182, св. друга, 75-87; књ. 183, св. трећа, 110-118.

19 Нав. дело, 40.

20 Нав. дело, 40-41. 
ручни потпис: „Царьсскаго Величаньства Полковникь и Кавалерь Михаиль Милорадовичь”.

На 420. листу је забележено:

„Сие историе (иза описа Италије) исписаше се из книге, кою наче на Москви грешьни азь Михаиль Милорадовичь польковникь и кавалиерь царьскаго пресветлаго величаньства. Си книга Николе Лековича од Никшића и саписасе на 1714 сентемра - 25 - на Москв”

На основу бележака, Павле Ровински је закључио да је Милорадовићев Зборник преписан са зборника „који је припадао архимандриту требињског манастира, Јоанићију, који је тако исто преписан с тре 6 и њ ског ље топ иса”, те је „овај последњи и први извор”21. Изводе из Зборника (422 л.4) Ровински је поделио у четири целине: 1. Из српског љетописа, 2. Сказаније о кнезу Лазару и косовском боју, 3. Опис Италије и 4. Садржина. Највећи део Милорадовићевог Зборника чини летопис. „Зборници ове врсте - каже Павле Ровински - обично носе наслове: хронограф, пролог или собраније, цароставник или староставник, тројадик"22. Изучавајући хронографе, Иларион Руварац²3 је утврдио да је тројадик манастира Шишатовца преписан с тројадика, који је 1654. монах Исаија писао у манастиру Требињу (Радосав, свештеник цркве св. Николе преписивао је 1702. у Мохачу цароставник шишатовачког манастира). Хронограб требиюски из 1654. налази се у Збирци рукописа манастира Савине (под бр. 16, а по каснијим записима види се да је књига обновљена у Савини) књига је обновљена 1746. о трошку јеромонаха Симеона Марковића - Савинца; белешка на предњој корици архимандрита Нектарија из 1761. да је то „Хронограф” свето-успенске савинске обитељи; белешка епископа Герасима да је књига описана 1867. у СДМ, затим нестала из Савине па враћена (1885).

Није необично што се овај Хронограб или Тројадик из старе херцеговачке митрополије, из Требиња, нашао у манастиру Савини, нити је нелогична његова веза са Милорадовићевим 3борником, када се зна за миграције становништва из старе Херцеговине у Боку Которску. „Стиче се утисак да је од друге половине XVII века стара Херцеговина била најзрелија да постане прави наследник првих планова о обнови српске

21 Нав. дело, 45-46.

22 Нав. дело, 45.

${ }_{23}$ Иларион Руварац, О иароставнику и иароставним книгама, Срп. летопис, 1873, књ. 115, 38-43. 
државе, у чему је огромну улогу играо манастир Милешева са култом св. Саве који је из њега зрачио на све стране"24. Неки потомци из угледних херцеговачких породица, попут Милорадовића, Владиславића и других, нашли су се у руској служби. Антитурско расположење код хришћанског становништва шириле су и хајдучке дружине, из којих је и Млетачка Република попуњавала своју плаћеничку војску. Бегунцима из тих крајева давала је уточиште у Приморју, вршећи тако колонизацију становништва на напуштеним турским поседима. Велики број Херцеговаца преселио се у Боку Которску нарочито после млетачког освајања Херцег Новог у току морејског рата 1687. „Једна од најмасовнијих сеоба из Херцеговине у Боку, изведена (je) не у рату, него после њега"25, а бегунци су смештени у околину Новог и Рисна.

Масовна и убрзана имиграција херцеговачког становништва на подручје Боке, нагнала је Млечане да предузму и прву аграрну реформу. О припадницима главарског слоја, свештеницима, кнезовима, владикама и војводама, власти су водиле нарочиту бригу, али је после мировног уговора од 14. фебруара 1701, а поготово после прогласа генералног провидура од 1. априла 1701, којим се забрањује примање турских поданика у Далмацију, дошло до разочарења. Стога ће херцеговачки главари у првој половини 18. века, тражити нове заштитнике. Преко рођака који су се налазили у руској служби - Милорадовића, Владиславића, Стратимировића, Властелиновића, Љубибратића - успоставиће јаке везе са Русијом, која је у време Петра Великог била веома заинтересована за стару Херцеговину и Црну Гору. У том периоду настаје и Милорадовићев Зборник (1714-1715), Сава Владиславић, по жељи Петра Великог, преводи 1722. у Петрограду Кральевство Словена Мавра Орбина, те тако настаје његова Книга историограбија, из Русије стижу иконе, књиге и богати дарови. И док су Срби у Аустрији, у области Карловачке митрополије, 60-тих година били приморани да ослабе и прекину везе са Русијом, калуђери из млетачке Далмације у другој половини 18. века одлазе у Русију. Обраћање црквених словенских монаха Русији, извођено је уз посредовање угледних Срба у руској служби. Савински монаси траже духовну помоћ од украјинских, у Кијеву.

У контексту ових збивања, расположења и духовне климе, требало би видети и улогу Михаила Милорадовића и разлог за настанак таквог Зборника, у коме се, уз хронограф, нашло и Житије кнеза Лазара, спис

24 Дејан Медаковић, нав. дело, 13.

25 Глигор Станојевић, Први катастар краја из 1702. године, Гласник цетињског музеја VII, Цетиње, 1974, 129. 
који је својом садржином и поруком доприносио јачању националне свести. Житије односно рукописна Прича о боју косовском не представља само опис живота и смрт кнеза Лазара, већ је истовремено и историјат страдања и пропасти српске средњовековне државе на Косову 1389. Настала под утицајем писаних дела, пре свега Кральевства Словена Мавра Орбина, летописа, али и усменог предања и народних песама, Прича је сачувала целовит и завршни облик косовске легенде, па је и тумачење узрока пада под Турке израз таквога схватања. Без обзира да ли је можда миграцијама донета из старе Херцеговине, попут Хронографа требинског који се нашао у Савини, или је састављена у Боки, она је оличење духовне климе нашег живља на југу.

Занимљив је податак да се међу јунацима који су били на кнежевој вечери и у боју помињу Живан, Ђурица и Петар Костијевић, и по мишљењу Андрије Лубурића, Ђурица би могао бити дробњачки војвода Ђурјан, који је по народној традицији „водио Дробњаке на Косово”. У Причи се, поред многих личности, помиње и Реља или Рељица Омућевић, те није немогуће да је састављач Приче имао у свести адмирала Петра од Ивеља Охмућевића (16. век), чије су се политичке акције и антитурско расположење могли памтити у народу. Предање је уз косовске јунаке уносило и личности из каснијих времена, те су се тако сви заједно нашли у борби против Турака.

Текст Приче о боју косовском није случајно унет у 3борник Михаила Милорадовића, поготово ако се узме у обзир интересовање за српску историју у Русији у 18. веку. Јаке везе са постојбином омогућавале су Милорадовићу да до таквога текста дође. Сличност рукописа ММ и СА показује да су оба текста имала исти предложак. Старији, целовитији и, свакако ближи протографу, је Милорадовићев. СА рукопис преписивале су две личности и чак се по језику може слутити да су постојала и два предлошка. Рукописна Прича о боју косовском била је, без сумње, распрострањена широко и преписивана надалеко и врло дуго, чак до половине 19. века. ${ }^{26}$

Косовска легенда стварала се постепено и врло дуго а њен завршни облик сачувала је Прича о боју косовском. У нашим јужним крајевима, у Дубровнику и Боки Которској, у 16. веку, била је врло жива и присутна, па се тако поједини елементи легенде налазе у делима многих писаца и историчара, у талијанском преводу Јована Дуке, код Лудвига Туберона Цријевића и нарочито у Кралевству Словена Мавра Орбина (Пезаро, 1601). Састављач рукописне Приче преузимао је предање о косовском

${ }^{26}$ Јелка Ређеп, нав. дело, 285. 
боју из писаних дела, пре свега од Орбина, али и директно. Интерполирани стихови (десетерачки и други), сведоче о постојању незабележених косовских песама. Стога је за генезу настанка овога дела од велике важности то што постоје записи песама с краја 17. и почетка 18. века. То су четири бугарштице, три из Дубровника и једна из Пераста. „Дубровачке бугарштице о косовској бици налазе се у рукописној збирци Попијевке словинске, коју је по речима Мирослава Пантића ${ }^{27}$ - 1758. средио, прикупивши за њу песме из ранијих, туђих и властитих рукописа, ерудита и историчар дубровачки Иван Марија Матијашевић” (1714-1791). Прву од те три, којој је Матијашевић дао дуги наслов Како Милош Драгиловић или Кобилић рағен на Косову на 15. липағьа 2.2 1389. погину и шта нареди на кониу од живота и поручи Вукосави, љууби својој, по својој пуници Милици, льуби кнеза Лазара кнеза од Србији, а кћере Угльеше Мрнавчића, записао је стриц Ивана Марије историчар и књижевни зналац Ђуро Матијашевић (1670-1728). Друге две забележио је песник Јозо Бетондић (1709-1764) и то су: Кад је погинуо кнез Лазар и Милош Кобиловић на Косову и Како се свадио Милош Кобиловић и вук Бранковић. Прве две бугараштице објавио је Валтазар Богишић у својој збирци ${ }^{28}$, а трећу А.Ф. Гиљфердинг у свом путопису $1859^{29}$. У намери да укажемо на везу Приче и песама, поредили смо ове, али и друге, десетерачке косовске песме ${ }^{30}$, и дошли смо до закључка да Прича и Богишићева песма бр.1 имају доста заједничког, да Прича нема никаквих сличности са песмом бр. 2, а да трећа, коју је објавио Гиљфердинг, обрађује мотив свађе Лазаревих кћери и зетова, као Орбин и Прича.

Четврту, (Бугарштииу о косовском боју), приредио је и објавио Мирослав Пантић ${ }^{31}$. Она се налази у перашком рукопису с краја 17. века, заједно са драмом непознатог Пераштанина Бој кнеза Лазара и Милоша Ковиљића и издајника Вука Бранковића и девет браће Југовића на Косову пољу на 24 иуюа годиште 1348. Рукопис је нашао Срећко Вуловић у патрицијској бокељској породици Смећа, проучио га и покушао да одгонетне аутора, јер рукопис нема насловне стране. Вуловић се колебао, „рука која је тај рукопис исписала за њега је и даље могла бити рука Андрије

27 Мирослав Пантић, Перашка бугарштица о косовском боју, Расковник, 1989, XV, бр. 55-56, 74.

${ }_{28}$ Народне пјесме из старијих највише приморских записа, Биоград, 1878, бр. 1 и 2.

29 А.Ф. Гильфердинг, Поъздка по Гериеговинъ, Босніи и Старои Сербіи, С. Петербург, 1859.

30 Јелка Ређеп, нав. дело, 248. страна и даље.

31 Расковник, 1898, XV, бр. 55-56, 73-84. 
Змајевића, али исто толико рука писара већега рукописа, тојест Николе Буровића, како одскора знамо" 32 . По Пантићу, коначно разрешење загонетке било би могуће само ако би се тај рукопис видео, а њега више нема. „Лако може бити да је Змајевић, ако је тај записивач он, или Никола Буровић, што је далеко вероватније, у ствари творац бугарштице, било да jу је сам испевао, или је пак удесио и приредио према некој бугашртици истога предмета која је послужила као основа"з3. Анализирајући бугарштицу, Мирослав Пантић доказује да она „нема неке веће уметничке вредности" 34 , и да је њен значај историјски а не књижевни.

Пишући о рукописној Причиㅜㄴ, указали смо на велику сличност овога дела и драме Бој Кнеза Лазара од непознатог Пераштанина с краја 17. века, сматрајући да је састављач Приче имао пред собом и овај текст и из њега преузимао поједине одломке и стихове. Перашка бугарштица има много заједничког и са драмом, са којом се налази и у истом рукопису, и са рукописном Причом. Милош је Ковиљић и у драми и у песми, оба дела почињу са причом о свађи Лазаревих кћери па зетова, Видосава је Вукова а Мара Милошева жена у оба текста. Исти је редослед казивања у бугарштици, драми и Причи. Сестре се свађају око јунаштва мужева а Вук је клеветник из освете. Само у бугарштици, као код Орбина, Милош и туче Вука, док му у друга два дела само прети. Детаљ, да Видосава моли Милоша да више не туче Вука, не постоји ни у једном другом тексту. Лазар наздравља Милошу на вечери, али у бугарштици нема ређања јунака ни на вечери ни у боју. Ни бој, сукоб две војске, није у песми опеван. Милош одлази у турски табор са својим побратимима, Миланом и Иваном.

„Један другом вјеру дава; ту се мало опростише.

Ту ти мало починуше, пак у њеко доба усташе

Три добра јунака,

На ноге се усташе и подаше коњ’ма зоби;

Отидоше јездећи пут табора царевога,

Три добра јунака"

исто као у Причи и драми, мада су ова два дела у овом делу опширнија и сличнија. Ни у бугарштици није изостао детаљ да Милош губи десну руку, као ни разговор Мурата, Лазара и Милоша под Муратовим шатором. У свим делима се подједнако прича о начину сахрањивања, али се

\footnotetext{
32 Мирослав Пантић, нав. дело, 77.

33 Нав. дело.

34 Нав. дело, 78.

35 Јелка Ређеп, нав. дело.
} 
не помиње зидање гроба од мрамора, већ се каже да „С’у тројицу бијаху у један гроб поставили".

Очигледна је веза сва три рукописа, забележене бугарштице, драме и Приче, дословно исти су поједини стихови и детаљи. Разумљиво је што су Прича и перашка драма опширнији и баш су ти делови текста веома слични. Извесно је да је на истој територији, у Боки, сачуван и рукопис Приче и цео перашки рукопис. Везу СА рукописа са драмом такође потврђује и слична грешка у оба текста. Наиме, у наслову драме је година 1348. а на последњем листу СА рукописа иза текста је 1349. Обе године на скоро исти (1348 и 1349) погрешан начин датирају време одигравања битке на Косову. Можемо се само домишљати да је непознати састављач Боја Кнеза Лазара помешао годину прве косовске битке (1389) са трећом (1448), те је забележио 48. годину а оставио 14. век; преписивач СА рукописа је можда случајно или намерно само изменио 48. у 49. годину али не и у 1389. На основу такве грешке могло би се слутити да је преписивач Приче, односно СА варијанте, нашао годину у драми, но то још увек није сигуран ни довољан доказ за разрешење питања првенства Приче о боју косовском и драме Бој Кнеза Лазара. Дајући првенство Причи (Повести), Мирослав Пантић наглава да је „далеко претежнија од тог утврђивања ко је коме послужио као извор, без икакве сумње околност да је тим преузимањем начињен још један од не тако честих, па отуда још драгоценијих, додира између двеју литература, једне оствариване у православној средини и писане ћирилицом, и друге, настале међу католицима и фиксиране латиницом"36. Време настанка, па и односа са драмом, моћи he ce прецизније одредити након критичког издања рукописне Приче. Чињеница да је једна варијанта сачувана у манастиру Савини, потврђује тезу о јужном пореклу овога дела, без обзира на то да ли је крајем 17. или на почетку 18. века састављена у старохерцеговачком залеђу и миграцијама донета у Боку, или је у њој настала у атмосфери националног заноса и антитурског расположења. Перашка бугарштица о косовском боју има више сличности са Причом но остале, дубровачке бугарштице. Забележене косовске бугарштице, али и драма непознатог Пераштанина и Прича о боју косовском, указују и на старији слој народних песама о боју на Косову 1389. године.

36 Мирослав Пантић, Кнез Лазар и косовска битка у старој књижевности Дубровника и Боке Которске, Београд, 1975, 382. 
Jelka Ređep

LE MANUSCRIT DE SAVINE DE „LA VIE DU PRINCE LAZARE”

Résumé

Parmi de maints manuscrits du monastère Savine, c'est dans Le Recueil des apocryphes que l'on trouve une variante, jusquà maintenant inconnue, et écrite à la main, du Récit de la bataille de Kossovo, intitulé „L' Histoire de la Vie du Prince Lazare et du Capitaine Miloche et d'autres seigneurs serbes qui avait eu lieu au champs de Kossovo. C'est la $36^{0}$ version du Récit écrit à la main, composé au sud, aux Bouches de Cottoro, ou bien au Monténégro. Si lon compare Le Manuscrit de Savine (SA) aux autres variantes du Récit écrit à la main, ou peut bien remarquer qu'il est plus proche des manuscrits parmi lesquels les plus anciens sont ceux MM (1714-1715) et UB (1715-1725) que du groupe de manuscrits analogues au manuscrit $\mathrm{G}$ (1727).

La question de la provenance du manuscrit SA, ainsi que de celle du Récit écrit à la main, en général, nous l'avons prise en considération dans le contexte des événements historiques aux Bouches de Cattaro à la fin du XVII e siècle et au commencement du XVIII siècle, au moment où les habitants de l'ancienne Herzégovine y arrivaient grâce aux migrations. De même, on a consacré beaucoup d'attention dans le présent ouvrage aux chants populaires épiques dits „bugaršticas”, parlant de la bataille de Kossovo (les trois chants de Doubrovnik et l'un de Pérast), tout en soulignant une grande ressemblance avec celui de Pérast. Le rapport est evident entre ces trois textes provenant des Bouches de Cattaro, notamment entre celui du manuscrit SA, c'est-à-dire du Récit, celui-ci du drame sur la bataille de Kossovo par un habitant anonyme de Pérast de la fin du XVII e siècle et celui-là du chant populaire épique dit „bugaraštica” de Pérast, se trouvant dans le même manuscrit que le drame en question. En même temps, ces trois texts mettent en lumière un stratum plus ancien des chants populaires sur la bataille de Kosovo. 